\title{
Physico-chemical characteristics of Jharkhand and West Bengal thermal springs along SONATA mega lineament, India
}

\author{
Hemant K Singh ${ }^{1, *}$, D Chandrasekharam ${ }^{1}$, O Vaselli ${ }^{2}$, G Trupti ${ }^{1}$, \\ B Singh ${ }^{1,3,4}$, Aref Lashin ${ }^{5,6}$ and Nassir Al Arifi ${ }^{7}$ \\ ${ }^{1}$ Department of Earth Sciences, Indian Institute of Technology, Mumbai 400 076, India. \\ ${ }^{2}$ Department of Earth Sciences, University of Florence, Via La Pira 4, I-50121 Firenze, Italy. \\ ${ }^{3}$ IITB-Monash Research Academy, Indian Institute of Technology Bombay, Mumbai 400 076, India. \\ ${ }^{4}$ Civil Engineering Department, Monash University, Clayton, Melbourne 3800, Australia. \\ ${ }^{5}$ King Saud University, College of Engineering - Petroleum and Natural Gas Engineering Department, \\ Riyadh 11421, Saudi Arabia. \\ ${ }^{6}$ Geology Department, Benha University, P.O. Box 13518, Benha, Egypt. \\ ${ }^{7}$ King Saud University, College of Science - Geology and Geophysics Department, P. O. Box 2455, \\ Riyadh 11451, Saudi Arabia. \\ *Corresponding author.e-mail: hemantkrsingh25@gmail.com
}

The chemical and isotopic compositions of thermal springs located along the Son-Narmada-Tapti (SONATA) mega lineament in central India have been investigated. The issuing temperatures of the thermal waters vary from $31^{\circ}$ to $89^{\circ} \mathrm{C}$ for the thermal springs and $24^{\circ}$ to $25^{\circ} \mathrm{C}$ for the cold springs. These thermal springs are located on the Archean Chotanagpur Gneissic Complex (CGC) in the eastern part of peninsular India. The thermal springs are mostly alkaline in nature with $\mathrm{pH}$ varying from 7.5 to 9.5. Piper diagram suggests that the chemistry of the thermal waters is compatible with the granitic host rocks through which the waters circulate. Mineral saturation index suggests that the thermal waters are saturated with cristobalite and quartz at lower temperatures (less than $\sim 130$ to $150^{\circ} \mathrm{C}$ ), and calcite and forsterite at higher temperatures $\left(\sim 160^{\circ}\right.$ to $\left.250^{\circ} \mathrm{C}\right)$. The estimated reservoir temperature based on chemical geothermometers is in the range of $132^{\circ}-265^{\circ} \mathrm{C}$, which favours a medium enthalpy geothermal system. Oxygen isotope fractionation of Bakreswar and Tantloi thermal springs highlights a higher reservoir temperature than estimated by chemical geothermometer. Positive gravity anomalies over Bakreswar and Tantloi areas strongly suggest a basement/mantle upliftment or mafic intrusion which could account for the heat source close to the surface. However, the large negative gravity anomaly depression around the Surajkund and Katkamsandi thermal springs indicates presence of deep seated faults.

\section{Introduction}

The states of Jharkhand and West Bengal host a number of thermal springs with issuing temperatures varying between $31^{\circ}$ and $89^{\circ} \mathrm{C}$. In West Bengal, these thermal springs occur at Bakreswar $\left(23^{\circ} 52^{\prime} 48^{\prime \prime} \mathrm{N} ; 87^{\circ} 22^{\prime} 40^{\prime \prime} \mathrm{E}\right.$, Birbhum district) while in Jharkhand, they occur at Tantloi $\left(24^{\circ} 2^{\prime} 8^{\prime \prime} \mathrm{N}\right.$; $87^{\circ} 17^{\prime} 15^{\prime \prime} \mathrm{E}$, Dumka district), Surajkund $\left(24^{\circ} 8^{\prime} 58^{\prime \prime} \mathrm{N}\right.$; $85^{\circ} 38^{\prime} 43.14^{\prime \prime} \mathrm{E}$, Hazaribagh district), Katkamsandi $\left(24^{\circ} 6^{\prime} 5.6^{\prime \prime} \mathrm{N} ; 85^{\circ} 12^{\prime} 7.57^{\prime \prime} \mathrm{E}\right.$, Hazaribagh district) and Indrajurba $\left(23^{\circ} 49^{\prime} 59^{\prime \prime} \mathrm{N} ; 85^{\circ} 30^{\prime} \mathrm{E}\right.$, Ramgarh district).

Keywords. Hazaribagh thermal spring; Bakreswar and Tantloi thermal spring; geochemistry of thermal water. 
All these thermal springs issue through Chotanagpur Gneissic Complex (CGC) composed of calc-silicate, amphibolite, gabbro, pegmatite, and dolerite except the one at Indrajurba that flows through Gondwana sedimentary formations. The thermal springs at Tantloi with temperatures of $68^{\circ}-70^{\circ} \mathrm{C}$ are located on ENE-WSW fault, while the Bakreswar thermal springs are located over NNW-SSE trending fault. The thermal springs at Surajkund lie over E-W trending fault (figure 1).

Deb and Mukherjee (1969), Bandyopadhyay and Nag (1989), and Majumdar et al. (2005, 2009) studied the chemical composition of Bakreswar and Tantloi thermal springs earlier. The geochemical signatures of the thermal springs show temporal variation with a few ions like $\mathrm{Na}, \mathrm{Cl}$, and $\mathrm{SiO}_{2}$ recording major deviation. In the present paper, we report new chemical and isotope data on the above thermal springs and discuss the evolution of the thermal springs in the light of original gravity data and also point out the power generation capacity of this thermal province.

\section{Geotectonic setting of the area}

The Chotanagpur Gneissic Complex (CGC) of eastern peninsular India has undergone different tectonic activities from Precambrian onwards (Sarkar 1982) to Cenozoic Era (Dunn 1939, 1941; Ghosh 1948; Desikachar 1974; Shanker 1991). Deep circulation of meteoric waters in CGC along the fracture zones and ongoing tectonic movements resulted in several thermal manifestations over the period (Deb and Mukherjee 1969).

The basement rocks have four sets of vertical to subvertical joints trending NW-SE, NE-SW, ENE-WSW, and N-S (Nagar et al. 1996). A large number of dolerite dykes, trending parallel to the regional fractures, transect the granites (figure 1).

Tantloi thermal springs, controlled by a WNWESE trending fault, are situated $20 \mathrm{~km} \mathrm{NW}$ of Bakreswar and issue through CGC, comprising charnockite and porphyrytic granite gneiss. Gondwana formations that include Talchir shale (Pyrite content, Mukherjee 1964), boulder bed and gritty sandstone are also exposed north of Tantloi (Mukhopadhyay 1989; Mukhopadhyay and Sarolkar 2012) (figure 2). Other thermal springs at Surajkund, Katkamsandi, and Indrajurba are also located in the same geological setting.

\section{Methodologies}

Representative water samples were collected from the study area, comprising 15 thermal springs, one cold spring, and five groundwater samples. Two

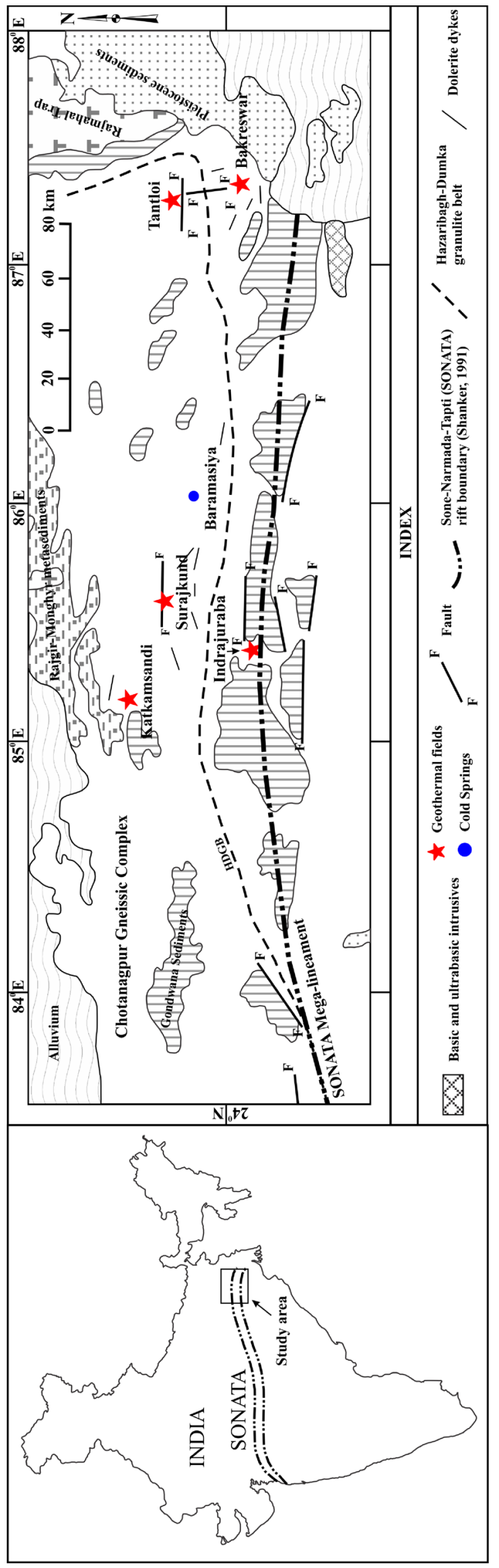

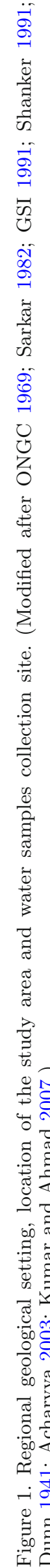



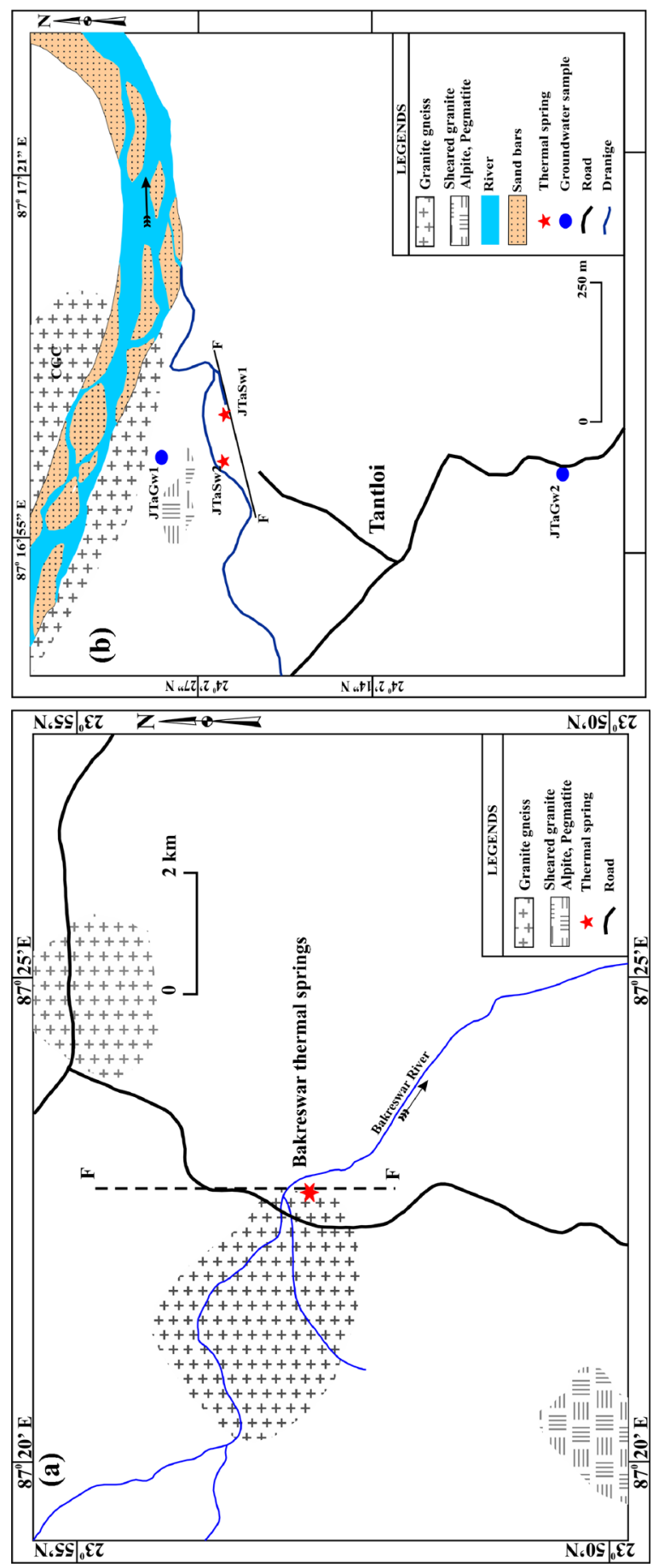

sets of water samples were collected. One set of water sample was acidified with $\mathrm{HNO}_{3}$ on site and the other set was stored at a lower temperature for future analysis (Giggenbach and Goguel 1988). The $\mathrm{pH}$ and temperature measurements were determined in the field using ORION pH meter. Water samples were analyzed for major ion concentrations. Cations and silica were analyzed using ICPAES. Sulphate concentration was measured with the aid of UV spectrophotometer; alkalinity was measured by $\mathrm{H}_{2} \mathrm{SO}_{4}$ titration, and chloride, by using ion selective electrode method (table 1). These analyses were carried out as per the standard procedures (APHA 1977). The analyses of oxygen and hydrogen stable isotopes were carried out at the Department of Earth Sciences, University of Florence, Italy.

\section{Results and discussion}

\subsection{Hydrogeochemistry}

Ground waters of the study area are near neutral to slightly alkaline $\left(\mathrm{pH}=6.9-7.8\right.$ at $\left.25^{\circ} \mathrm{C}\right)$ with dissolved solids varying from 367 to $612 \mathrm{mg} / \mathrm{L}$. EC range from 548 to $913 \mu \mathrm{S} / \mathrm{cm}$ and $\mathrm{SiO}_{2}$ content in groundwater is $18-86 \mathrm{mg} / \mathrm{L}$. The groundwater of the study area is of $\mathrm{Na}-\mathrm{HCO}_{3}$ type (table 1).

The thermal springs record wide range of surface temperatures varying from $31^{\circ}$ to $89^{\circ} \mathrm{C}$. They are near neutral to moderately alkaline $(\mathrm{pH}=$ $7.5-9.5$ at $25^{\circ} \mathrm{C}$ ) in nature with TDS varying from $461-924 \mathrm{mg} / \mathrm{L}$ (table 1 ). $\mathrm{SiO}_{2}$ content is higher in thermal waters $(97-143 \mathrm{mg} / \mathrm{L})$ relative to groundwater $(18-86 \mathrm{mg} / \mathrm{L})$. Amongst the cations, $\mathrm{Na}$ is predominant $(92-198 \mathrm{mg} / \mathrm{L})$, while the concentration of $\mathrm{K}$ and $\mathrm{Ca}$ is low $(<4 \mathrm{mg} / \mathrm{L})$ except samples 8 to $12 . \mathrm{Mg}$ content $(0.01-1.2 \mathrm{mg} / \mathrm{L})$ is very less in the thermal springs.

All the water samples are plotted in the Piper diagram (Piper 1944) (figure 3). It is seen from figure 3 that the thermal springs are of $\mathrm{Na}-\mathrm{Cl}$ type except for Indrajurba thermal spring of the $\mathrm{Na}-\mathrm{HCO}_{3}$ type. The cold spring (sample 16) shows typical groundwater character and is $\mathrm{Ca}-\mathrm{HCO}_{3}$ type.

\subsection{Anion variation}

Water samples from the study area were plotted in the $\mathrm{Cl}-\mathrm{SO}_{4}-\mathrm{HCO}_{3}$ diagram (figure 4) to select suitable samples for estimation of reservoir temperature as suggested by Giggenbach (1988). As seen in figure 4, most of the thermal waters of the study area fall within the $\mathrm{Cl}$ field and samples $3,4,5$, and 7 fall within the chloride/mature water field of Giggenbach (1988). These samples may be 
Table 1. Chemical parameters of water samples from the study area (major ion concentration, TDS in mg/l, and EC in $\mu S / \mathrm{cm})$.

\begin{tabular}{|c|c|c|c|c|c|c|c|c|c|c|c|c|c|c|c|}
\hline $\begin{array}{l}\text { Sl. } \\
\text { no.* }\end{array}$ & $\begin{array}{c}\text { Sample } \\
\text { name }\end{array}$ & $\mathrm{pH}$ & ${ }^{\circ} \mathrm{C}$ & $\mathrm{EC}$ & TDS & $\mathrm{Na}^{+}$ & $\mathrm{K}^{+}$ & $\mathrm{Ca}^{++}$ & $\mathrm{Mg}^{++}$ & $\mathrm{Cl}^{-}$ & $\mathrm{HCO}_{3}^{-}$ & $\mathrm{SO}_{4}^{--}$ & $\mathrm{SiO}_{2}^{-}$ & $\begin{array}{c}\delta^{18} \mathrm{O} \\
(\% 00)\end{array}$ & $\begin{array}{c}\delta \mathrm{D} \\
(\% 0)\end{array}$ \\
\hline 1 & JTaSw1 & 9.5 & 70 & 731 & 490 & 92.2 & 2.1 & 1.3 & 0.01 & 97.5 & 30 & 29.4 & 98.6 & -4.1 & -30.9 \\
\hline 2 & JTaSw2 & 9.3 & 68 & 688 & 461 & 95.4 & 2.4 & 1.5 & 0.15 & 99.0 & 25 & 35.6 & 101.2 & -4.3 & -31.3 \\
\hline 3 & WBSw1 & 9.4 & 55 & 739 & 495 & 112.0 & 2.2 & 1.3 & 0.01 & 128.0 & 35 & 19.8 & 98.6 & -2.7 & -24.8 \\
\hline 4 & WBSw2 & 9.2 & 65 & 725 & 486 & 109.0 & 2.3 & 1.2 & 0.01 & 115.0 & 55 & 18.2 & 92.6 & -2.6 & -24.3 \\
\hline 5 & WBSw3 & 9.3 & 56 & 769 & 515 & 115.3 & 2.2 & 1.3 & 0.01 & 122.5 & 65 & 12.8 & 97.9 & -2.3 & -24.9 \\
\hline 6 & WBSw4 & 7.7 & 42 & 876 & 587 & 114.1 & 3.3 & 3.6 & 0.19 & 112.5 & 135 & 17.8 & 101.0 & -2.7 & -24.1 \\
\hline 7 & WBSw5 & 9.3 & 70 & 749 & 502 & 110.8 & 2.2 & 1.3 & 0.01 & 117.5 & 60 & 16.7 & 97.0 & -2.5 & -33.1 \\
\hline 8 & JSSw-1 & 8.5 & 89 & 988 & 662 & 141.2 & 8.0 & 2.3 & 0.01 & 136.2 & 45 & 69.0 & 130.4 & NA & NA \\
\hline 9 & JSSw-2 & 8.4 & 31 & 1379 & 924 & 198.8 & 19.2 & 23.2 & 0.90 & 159.0 & 115 & 152.5 & 128.6 & NA & NA \\
\hline 10 & JSSw-3 & 8.3 & 32 & 1152 & 772 & 147.6 & 9.3 & 8.9 & 0.40 & 96.5 & 75 & 181.1 & 127.5 & NA & NA \\
\hline 11 & JSSw-4 & 8.7 & 32 & 1106 & 741 & 149.2 & 11.1 & 9.7 & 0.30 & 135.0 & 71 & 79.2 & 143.0 & NA & NA \\
\hline 12 & JSSw-5 & 8.4 & 47 & 1063 & 712 & 150.4 & 8.2 & 3.3 & 0.01 & 126.4 & 65 & 89.4 & 135.0 & NA & NA \\
\hline 13 & JKSw-1 & 8.9 & 62 & 743 & 498 & 126.4 & 4.1 & 2.9 & 0.01 & 110.8 & 60 & 60.5 & 67.0 & NA & NA \\
\hline 14 & JISw & 7.9 & 35 & 770 & 516 & 119.3 & 2.9 & 8.0 & 1.20 & 54.5 & 215 & 14.1 & 50.6 & NA & NA \\
\hline 15 & JISw1 & 8.1 & 34 & 752 & 504 & 117.9 & 2.8 & 7.7 & 1.20 & 49.1 & 195 & 28.0 & 51.4 & NA & NA \\
\hline 16 & $\mathrm{JBaCw}$ & 7.4 & 25 & 409 & 274 & 12.5 & 1.5 & 30.5 & 13.70 & 26.0 & 135 & 7.2 & 23.8 & NA & NA \\
\hline 17 & JSGw-1 & 7.2 & 26 & 688 & 461 & 54.1 & 8.8 & 39.0 & 6.30 & 47.6 & 160 & 34.9 & 55.3 & NA & NA \\
\hline 18 & JKGw & 6.9 & 26 & 548 & 367 & 40.2 & 3.0 & 36.8 & 12.70 & 39.0 & 190 & 8.9 & 18.6 & NA & NA \\
\hline 19 & JTaGw1 & 7.8 & 27 & 660 & 442 & 43.2 & 1.5 & 25.7 & 6.34 & 32.5 & 180 & 4.3 & 74.2 & -4.6 & -36.4 \\
\hline 20 & JTaGw2 & 7.1 & 26 & 569 & 381 & 44.7 & 0.6 & 21.3 & 3.85 & 60.0 & 115 & 3.7 & 66.0 & -5.1 & -38.5 \\
\hline 21 & JTaGw3 & 7.5 & 25 & 913 & 612 & 67.7 & 1.5 & 34.5 & 15.62 & 75.0 & 235 & 10.2 & 86.4 & -4.6 & -36.7 \\
\hline
\end{tabular}

${ }^{*} 1-15$ : thermal spring waters; 16 : cold spring water; 17-21: groundwater samples.

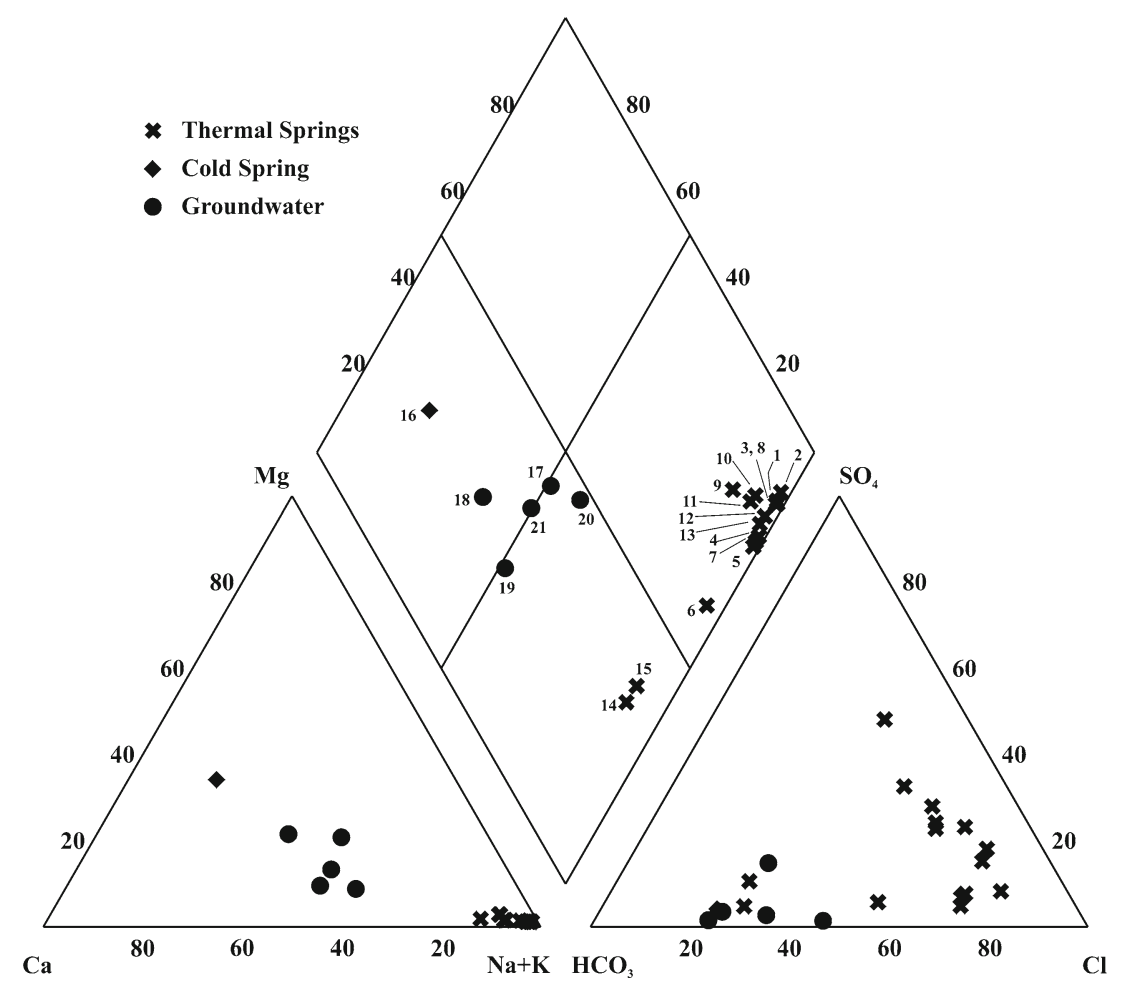

Figure 3. Piper trilinear diagram (Piper 1944) showing the geochemical variation of different water types from the study area.

considered as those that are not affected by any secondary processes (i.e., mixing with the near surface groundwater) during the ascent of the water to the surface. A few samples (Nos. 6, 14, 15) plot in the $\mathrm{HCO}_{3}$ field (figure 4) indicating process of mixing with the near surface ground water during their ascent to the surface. The plots of samples 9 , 10, and 12 trending towards the $\mathrm{SO}_{4}$ field could 


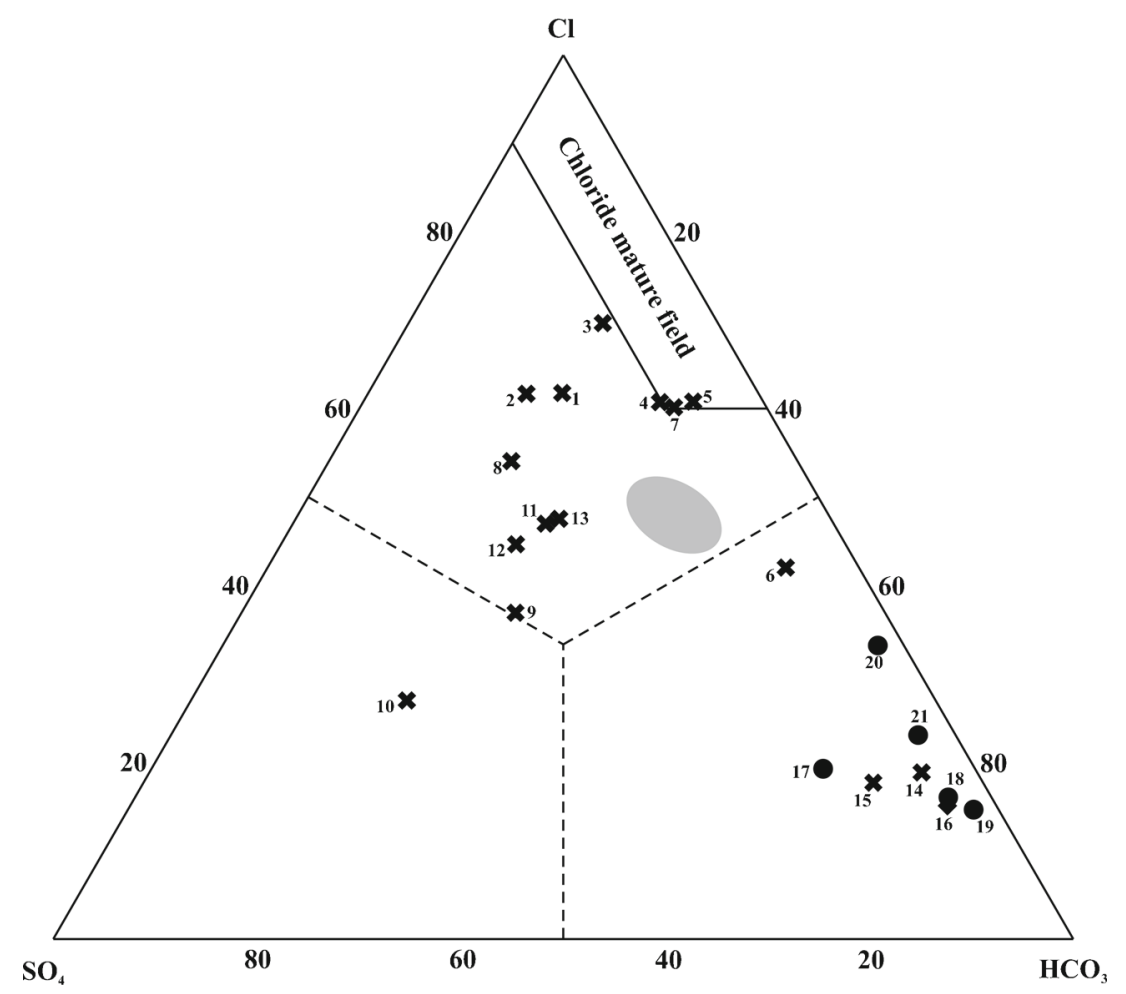

Figure 4. Cl- $\mathrm{SO}_{4}-\mathrm{HCO}_{3}$ diagram (Giggenbach 1988) showing the position of water samples from the study area, symbols are same as in figure 3. The grey ellipse shows the plots of earlier work by Majumdar et al. (2009).

Table 2. Estimated reservoir temperature of the study area thermal springs based on chemical geothermometry.

\begin{tabular}{|c|c|c|c|c|c|c|}
\hline \multirow[b]{2}{*}{ Sl. no. } & \multirow[b]{2}{*}{$\begin{array}{l}\text { Sample } \\
\text { name }\end{array}$} & \multicolumn{2}{|c|}{ Silica geothermometry } & \multicolumn{3}{|c|}{ Cation geothermometry } \\
\hline & & $\begin{array}{l}\text { No. steam } \\
\text { loss }\end{array}$ & $\begin{array}{l}\text { Maximum } \\
\text { steam loss }\end{array}$ & $\begin{array}{c}\mathrm{Na}-\mathrm{K} \\
\text { (Fournier 1983) }\end{array}$ & $\begin{array}{c}\mathrm{Na}-\mathrm{K} \text { (Giggenbach } \\
\text { et al. } 1983 \text { ) }\end{array}$ & $\begin{array}{l}\mathrm{Na}-\mathrm{K}-\mathrm{Ca} \text { (Fournier } \\
\text { and Truesdell 1973) }\end{array}$ \\
\hline 1 & JTaSw1 & 136.4 & 132.1 & 117.0 & 137.3 & 178.1 \\
\hline 2 & JTaSw2 & 137.9 & 133.3 & 121.9 & 142.1 & 103.2 \\
\hline 3 & WBSw1 & 136.4 & 132.1 & 109.3 & 129.9 & 176.9 \\
\hline 4 & WBSw2 & 132.9 & 129.1 & 111.7 & 132.1 & 175.1 \\
\hline 5 & WBSw3 & 136.0 & 131.7 & 107.8 & 128.4 & 176.1 \\
\hline 7 & WBSw5 & 135.5 & 131.3 & 109.9 & 130.4 & 176.1 \\
\hline 8 & JSSw-1 & 152.6 & 145.6 & 172.7 & 190.7 & 238.2 \\
\hline 9 & JSSw-2 & 151.7 & 144.9 & 214.0 & 229.5 & 212.3 \\
\hline 10 & JSSw-3 & 151.2 & 144.5 & 180.3 & 197.9 & 174.5 \\
\hline 11 & JSSw-4 & 158.2 & 150.3 & 192.9 & 209.7 & 193.0 \\
\hline 12 & JSSw-5 & 154.7 & 147.3 & 170.0 & 188.1 & 265.0 \\
\hline 13 & JKSw-1 & 116.0 & 114.7 & 136.3 & 156.0 & 238.9 \\
\hline
\end{tabular}

be the result of reaction with pyrite bearing Gondwana sediments and Rajmahal volcanics that are exposed towards the northern part of the area of investigation (figure 1).

\subsection{Geothermometry}

Estimated reservoir temperatures based on silica concentration in thermal waters (Fournier 1973) and cation geothermometers are given in table 2 .

Giggenbach (1988) proposed $\mathrm{Na}-\mathrm{K}-\sqrt{ } \mathrm{Mg}$ ternary diagram for a more precise reservoir temperature estimation. The reactions involving $\mathrm{K}-\mathrm{Na}$, equilibrate at high temperatures and do not adjust quickly to the physical environment at shallow depths, thus giving high values of reservoir temperature. While reactions involving $\mathrm{K} / \sqrt{ } \mathrm{Mg}$, equilibrate at low temperatures and give very low reservoir temperatures. Giggenbach (1988) combined both $\mathrm{Na}-\mathrm{K}$ and $\mathrm{K} / \sqrt{ } \mathrm{Mg}$ thermometers and gave $\mathrm{Na}-\mathrm{K}-\sqrt{ } \mathrm{Mg}$ ternary diagram for estimating the reservoir temperatures. Thus for a more accurate estimation of the reservoir temperature, thermal waters of the study area were 


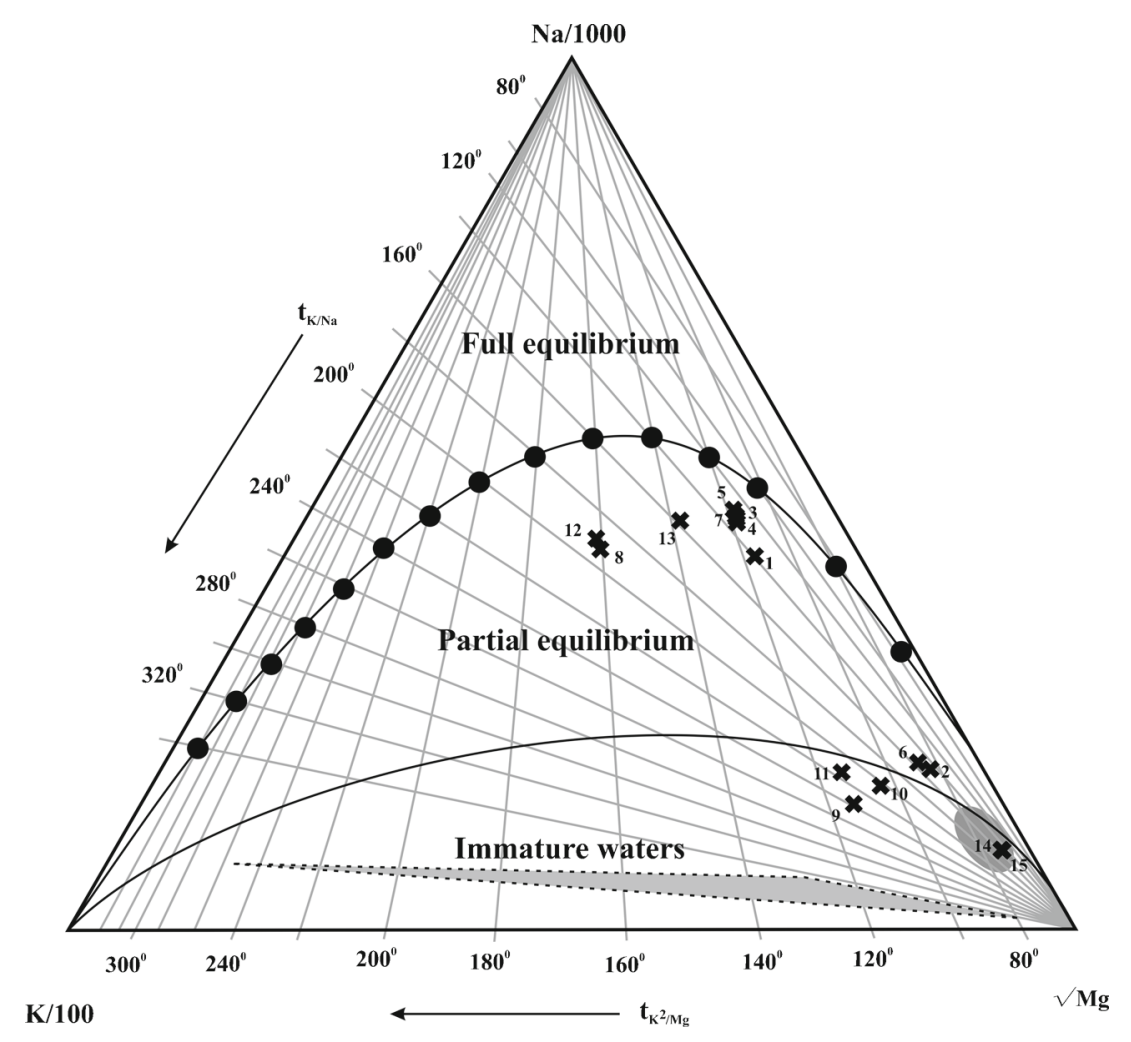

Figure 5. $\mathrm{Na}-\mathrm{K}-\sqrt{ } \mathrm{Mg}$ geothermometer ternary diagram of Giggenbach (1988) showing the variation in study area thermal springs. The grey ellipse covers the plots of the previous work done by Majumdar et al. (2009).

plotted in the $\mathrm{Na}-\mathrm{K}-\sqrt{ } \mathrm{Mg}$ ternary diagram (figure 5).

Most of the thermal springs of the study area plot in the partial equilibrium field in figure 5 . The estimated reservoir temperature for Bakreswar (samples 3-7) varies from $120^{\circ}$ to $140^{\circ} \mathrm{C}$ while for Tantloi, the temperature is about $140^{\circ} \mathrm{C}$. For the sake of comparison, the field of thermal springs reported earlier from Bakreswar and Tantloi (Majumdar et al. 2009) is also shown in figure 5. The estimated reservoir temperature for Surajkund varies from $160^{\circ}$ to $190^{\circ} \mathrm{C}$ (samples $8-12$, table 1 ) and is much higher compared to others. All other thermal springs plot in the immature field of figure 5 .

\subsection{Mineral equilibrium and geothermometry}

Mineral equilibrium was calculated with the help of activity of the species in water samples over a range of temperatures. This is expressed for mineral $k$ in terms of $\log (Q / K)_{k}$ (Reed and Spycher 1984):

$$
\log \left(\frac{Q}{K}\right)_{k}=\log \prod^{i} a_{i, k}^{v_{i, k}}-\log K_{k}
$$

where $K$ is the equilibrium constant for mineral $k, a_{i, k}$ is the activity and $v_{i, k}$ is the stoichiometric coefficient of component species $i$ in the equilibrium mass action expression for mineral $k$, written with the mineral on the left-hand side. For supersaturated minerals, $\log (Q / K)_{k}$ value is greater than zero while it is less than zero for undersaturated minerals. Calculation of species in water samples were performed by PHREEQC (Parkhurst and Appelo 1999) with WATEQ4E thermodynamic database (Ball and Nordstrom 1991) included in the PHREEQC package.

The reservoir temperature of the study area calculated using $\mathrm{Na}-\mathrm{K}-\mathrm{Ca}$ geothermometer (Fournier and Truesdell 1973$)$ is $120^{\circ} \mathrm{C}$ and $110^{\circ}-190^{\circ} \mathrm{C}$ by the $\mathrm{Na}-\mathrm{K}-\sqrt{ } \mathrm{Mg}$ diagram (figure 5 ), while by $Q / K$ plot (figure 6), the temperatures estimated are $130^{\circ}-180^{\circ} \mathrm{C}$. Figure 6 indicates that the geothermal water is in equilibrium with calcite and quartz, which may be a reflection of the fluids being derived from a much deeper source where the host rock is granite gneiss and later interacting with the enclaves of calc-silicate rocks at lower temperature at shallower depths. This accounts for the effects of different rates of re-equilibration of minerals with waters that are cooled during ascent (Reed and Spycher 1984).

\subsection{Oxygen and hydrogen isotope}

Groundwaters of the Bakreswar and Tantloi area vary in $\delta^{18} \mathrm{O}$ values from -3.8 to $-5.1 \%$ and $\delta \mathrm{D}$ 

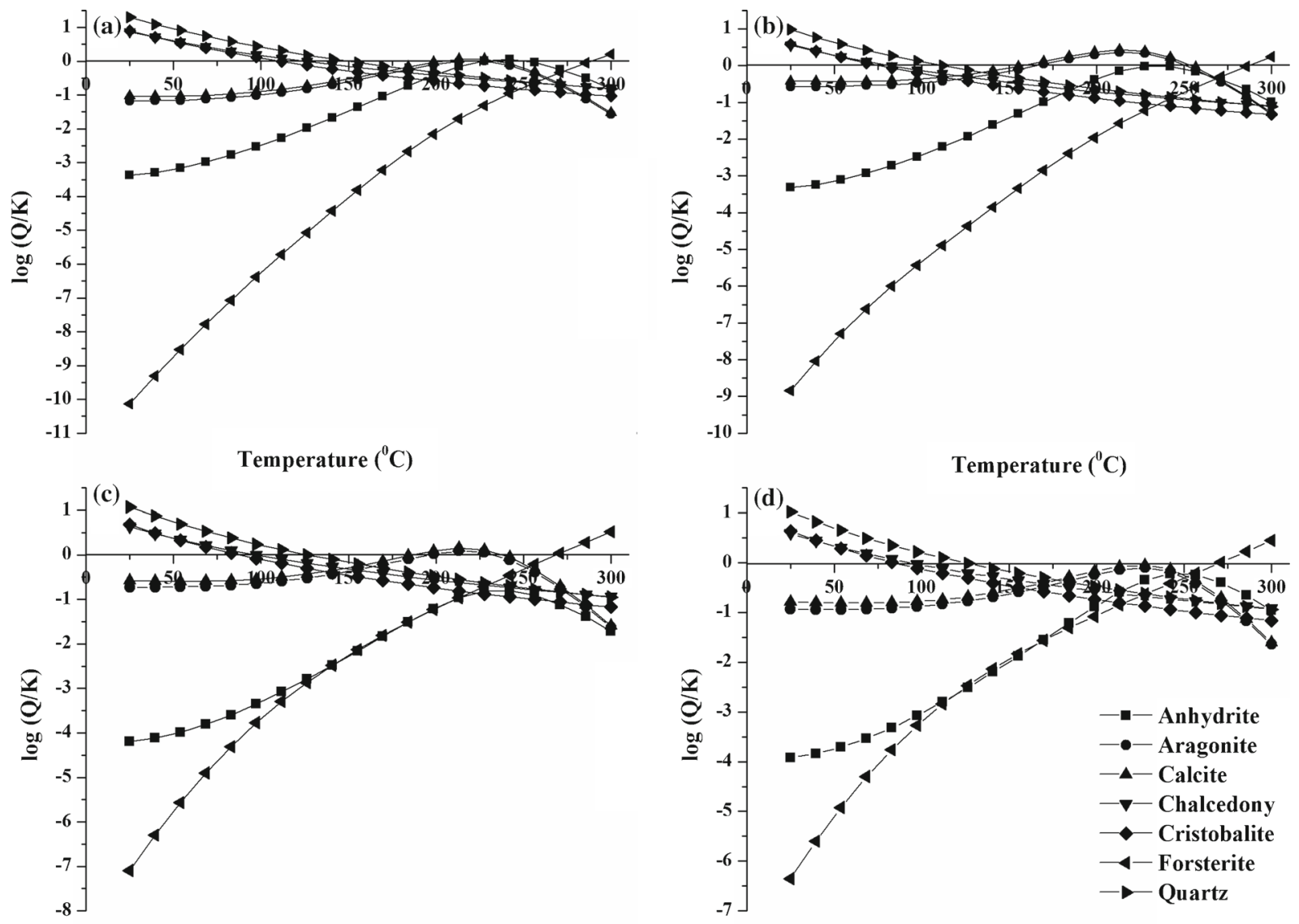

Temperature $\left({ }^{0} \mathrm{C}\right)$

Temperature $\left({ }^{0} \mathrm{C}\right)$

Figure 6. Mineral equilibrium diagram of (a) Surajkund, (b) Katkamsandi, (c) Tantloi, and (d) Bakreswar thermal springs of the study area.

value from -29.1 to $-38.5 \%$ (table 1 ). Thermal waters of the area give $\delta^{18} \mathrm{O}$ values in the range from -2.3 to $-4.3 \%$ and $\delta \mathrm{D}$ values in the range of -33.1 to $-24.1 \%$. The oxygen and hydrogen isotopic compositions of the water samples were plotted in the $\delta^{18} \mathrm{O}$ vs. $\delta \mathrm{D}$ diagram (figure 8 ). The position of the thermal waters with respect to the Indian meteoric water line (IMWL, IAEA 2008) shows 'oxygen shift' which signifies water-rock interactions above $220^{\circ} \mathrm{C}$ (Nuti 1991; Giggenbach and Soto 1992; Giggenbach 1992). Bakreswar thermal springs are clustered together except for Agnikund (sample \#7) probably due to steam separation, resulting in oxygen and hydrogen shift (Truesdell et al. 1977; Giggenbach 1992). Groundwater samples of the study area also show oxygen shift as in figure 7 , which strongly supports the thermal origin of the groundwater.

\subsection{Gravity anomaly}

Gravity anomaly map was prepared based on the terrain corrected Bouguer Gravity Anomaly map of India (GSI 2006). The study area shown in figure 8 is characterized by high positive anomalies (30 mGal).

The gravity anomaly profiles were prepared along two $\mathrm{E}-\mathrm{W}$ sections passing through Bakreswar and Tantloi thermal spring sites respectively, and also one NNW-SSE profile passing through both the thermal springs (figures 8, 9a). The $\mathrm{E}-\mathrm{W}$ profile shows a large area of positive anomaly in Bakreswar and Tantloi geothermal fields. The profile from east to west over Bakreswar shows sudden change in gravity anomaly reaching up to 30 $\mathrm{mGal}$, and then suddenly decreases to the negative anomaly. This behaviour of gravity anomaly occurs due to the presence of the fault in the area trending N-S (Telford et al. 1990; Jacoby and Smilde 2009). The profile NNW-SSE shows sudden change in the anomaly over Tantloi, possibly due to the presence of the ENE-WSW trending fault. It is interesting to note that these major faults are close to the hydrothermal manifestations. The gravity anomalies over these geothermal fields could be ascribed to a combination of hydrothermal metamorphism 


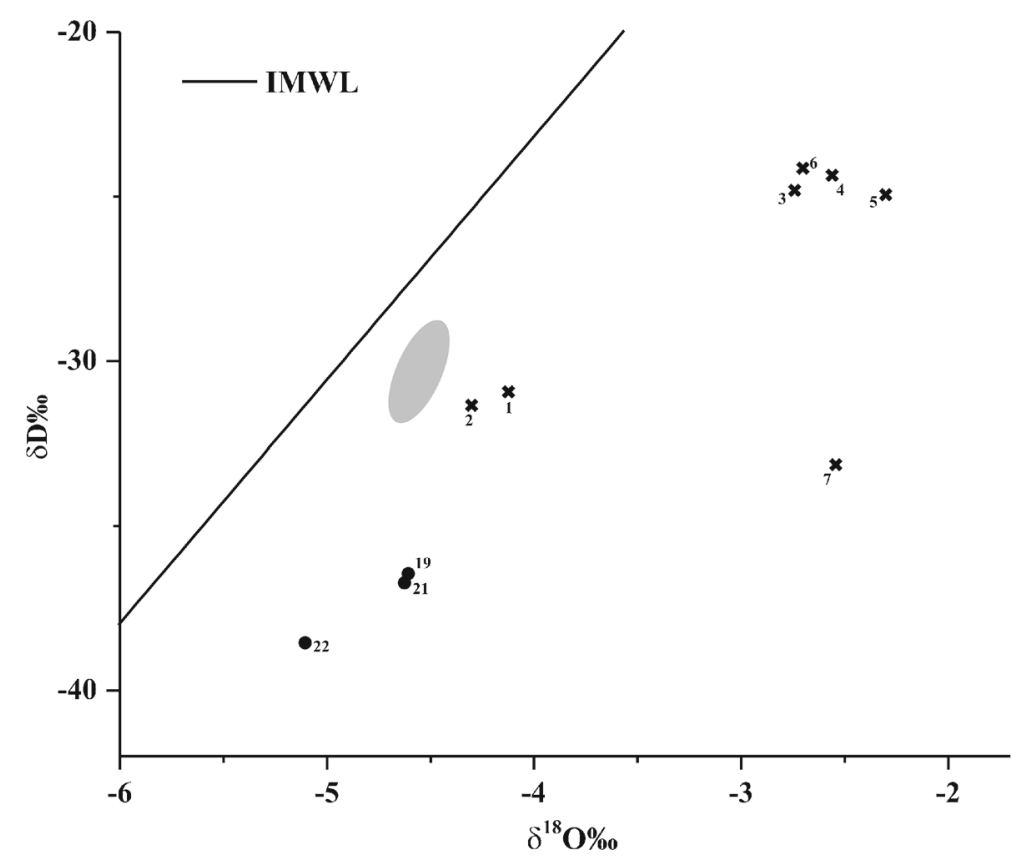

Figure 7. Oxygen and hydrogen isotope variation diagram of Bakreswar and Tantloi water samples. Symbols are same as in figure 3 and the grey ellipse represents data from Majumdar et al. (2005).

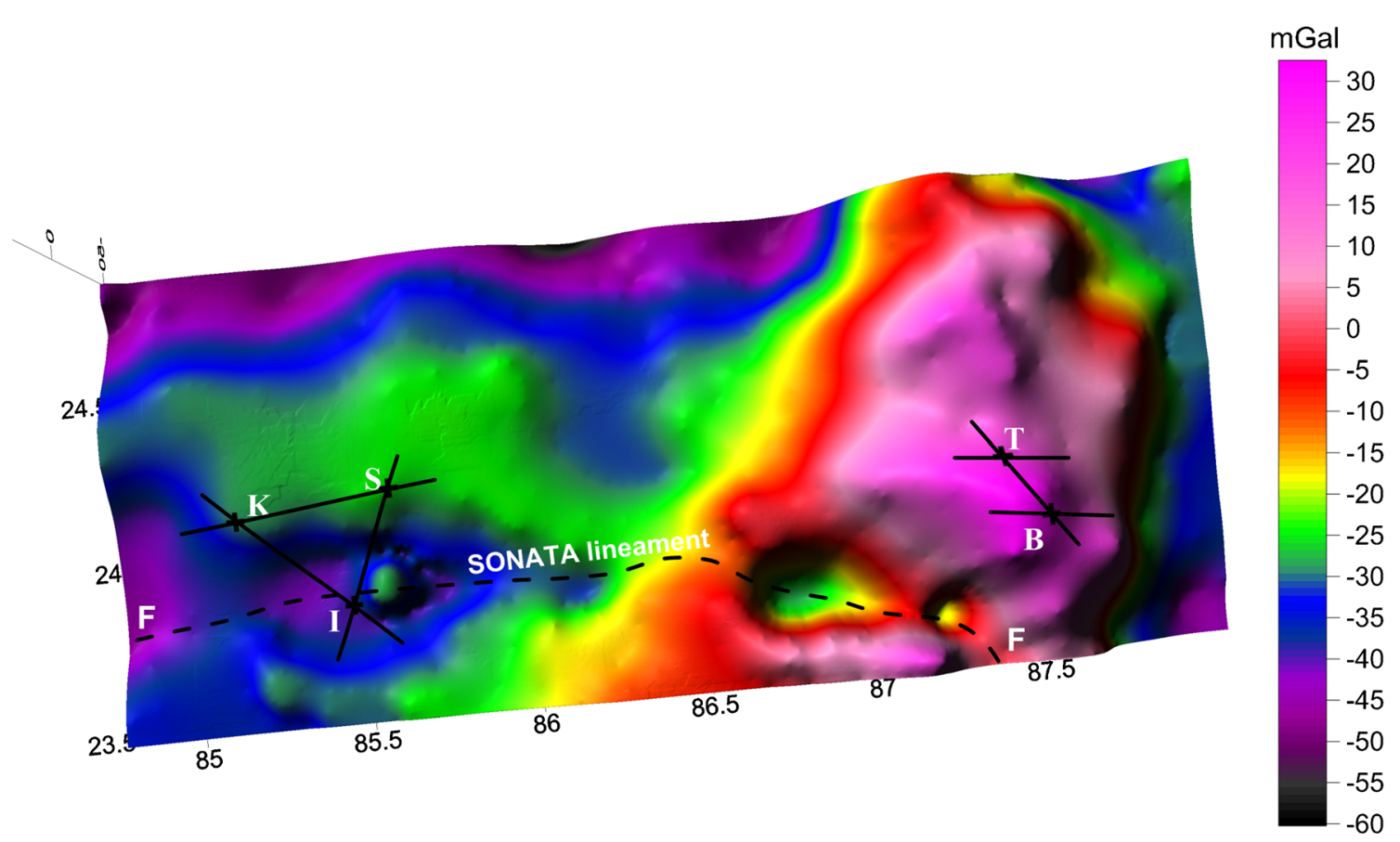

Figure 8. Bouguer gravity anomaly map (terrain corrected) of the study area where S: Surajkund; K: Katkamshandi; I: Indrajurba; B: Bakreswar and T: Tantloi; F-F: SONATA mega lineament. Solid black lines indicate line along which Bouguer gravity anomaly profiles are constructed and are shown in figure 9 (a and b).

of the sediments and concomitant local basement or mantle highs.

In the case of other geothermal sites, three gravity profiles were studied, two from Katkamsandi to Surajkund and Indrajurba and one from Surajkund to Indrajurba (figure 8). Katkamsandi, Surajkund, and Indrajurba thermal springs fall in the negative gravity anomaly zone with Indrajurba thermal springs falling in the lowest negative anomaly zone (figure 9b). A sudden change in the gravity 

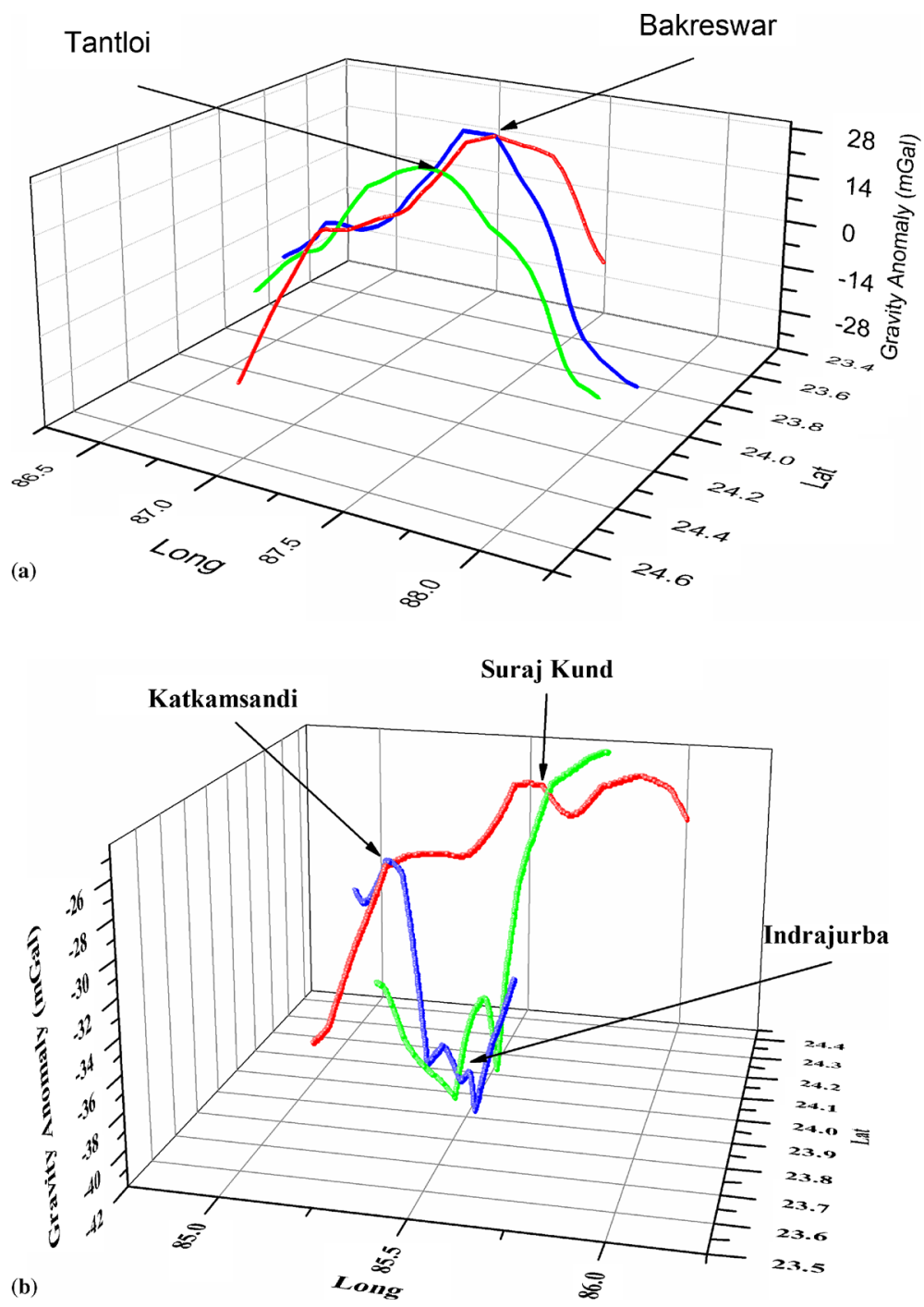

Figure 9. Gravity anomaly profile around (a) Bakreswar and Tantloi geothermal field; (b) Surajkund, Katkamsandi and Indrajurba geothermal fields. Profile tacks are shown with solid black lines in figure 8.

anomaly near Indrajurba along the SurajkundIndrajurba profile, may indicate a horst structure or a mafic intrusive facilitating propagation of thermal waters. Large variation in negative anomaly values between Surajkund, Katkamsandi, and Indrajurba can be related to deep seated faults in that area (ONGC (Oil and Natural Gas Commission) 1969). This geothermal province appears to be a part of the Son-Narmada-Tapi (SONATA) mega lineament, which runs parallel to the study area, and is most likely to rely on the source for the heat circulation in these thermal springs.

\subsection{Spectral analysis of gravity anomaly}

Energy spectrum analysis of gravity or magnetic anomaly has been widely studied by several researchers (Bhattacharyya 1966, 1978; Spector and Grant 1970; Gerard and Debeglia 1975) to decipher the subsurface structures. In addition to the bouger gravity interpretation made and discussed in the above section, this method is applied for the present field site to bring out quantitative interpretation of the subsurface structure to render further support to the inferences made above. Thus the Bakreswar gravity anomaly profile (figure 10) suggests that the basement is located at a shallow depth of $0.6 \mathrm{~km}$ as shown in figure 10 as $\mathrm{K} 1$ and $\mathrm{K} 2$. The depth along the profile $\mathrm{K} 2$ is 1.5 $\mathrm{km}$. Depth variation in both K1 and K2 sections is $0.7 \mathrm{~km}$, which suggests faults below Bakreswar geothermal site.

\section{Conclusions}

Thermal springs of the study area belong to $\mathrm{Na}-\mathrm{Cl}$ type except for two thermal springs that fall in the $\mathrm{Na}-\mathrm{HCO}_{3}$ field while the cold spring is of $\mathrm{Ca}-\mathrm{HCO}_{3}$ (figure 3). The groundwater, on the other 

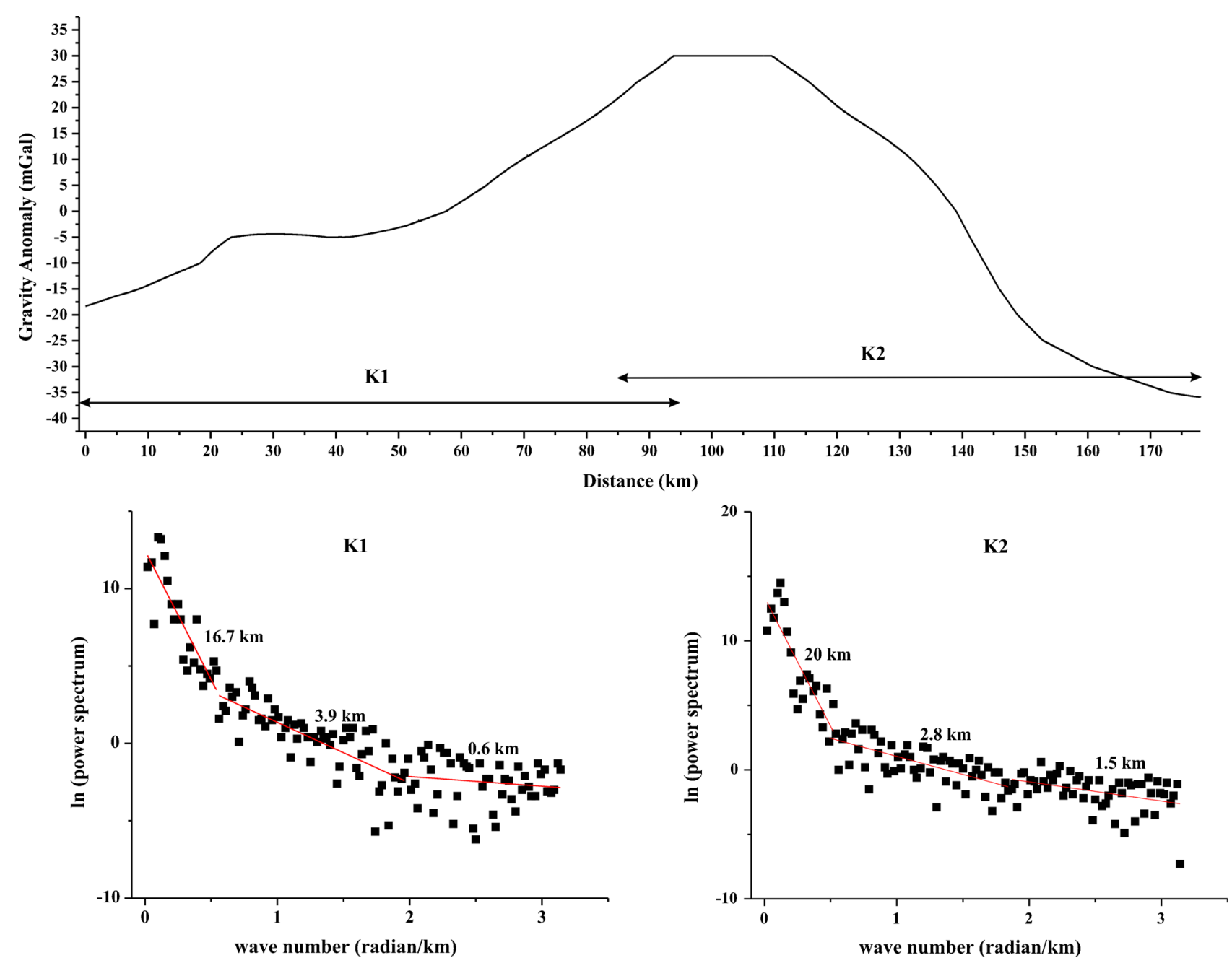

Figure 10. Gravity anomaly along the Bakreswar geothermal site, K1 and K2 is the length taken for spectral analysis to estimate the depth to anomalous sources.

hand, defines an array between the cold spring and the thermal spring indicating a large thermal spring component in the ground water. This is very well seen in the oxygen-hydrogen isotope diagram of Bakreswar and Tantloi geothermal field (figure 7) where the groundwater exhibits a large oxygen shift. The temperature estimated using the cation geothermometers yields a temperature much higher than reported in earlier studies (Majumdar et al. 2005, 2009). It is apparent that the ascending waters are reacting with the wall rock at temperatures greater than $220^{\circ} \mathrm{C}$. One of the thermal springs (sample 7) also shows a hydrogen shift indicating steam loss during its ascent (Nuti 1991; Giggenbach and Soto 1992; Giggenbach 1992, figure 7).

The presence of high He content (1.5\%) and low $\mathrm{Kr} / \mathrm{Xe}$ ratio (0.262) in thermal gases from Bakreswar and Tantloi (Ghose and Chatterjee 1980; Ghose et al. 1989) suggests that the thermal springs are ascending through high heat generating granites. This is further supported by high heat flow values reported $\left(200 \mathrm{~mW} / \mathrm{m}^{2}\right.$, Shanker 1988; Chandrasekharam 2000) in this area. The environment through which the above thermal springs are circulating appears to be similar to Tattapani thermal province in Chhattisgarh where the thermal gases contain high $\mathrm{He}$ content (1.54\%, Minissale et al. 2000) with high heat flow value $\left(280 \mathrm{~mW} / \mathrm{m}^{2}\right.$, Chandrasekharam and Chandrasekhar 2010). Both deep seated fault system (SONATA) and high heatgenerating granites appear to be the main factors for circulating the thermal springs of this area.

In case of Surajkund, Katkamsandi, and Indrajurba thermal springs, the plots (figure 3 ) although similar to Bakreswar and Tantloi thermal springs, the Surajkund thermal spring registered higher reservoir temperature $\left(190^{\circ} \mathrm{C}\right.$, figure 5) compared to other thermal springs. As reported above, the influence of pyrite present in the Talchir shales and Rajmahal Traps is very well reflected in the shift of the plots towards the sulphate fields as in figure 3 . 
The gravity anomaly pattern gives indication of mantle upwarp in this region supported by the presence 100-105 Ma (McDougall and McElhinny 1970) Rajmahal Traps in north of Tantloi. Thus, the geothermal system in the Bakreswar-Tantloi area is controlled by both deep seated structures and high heat-generating host granites. It has to be seen further whether any mantle $\mathrm{He}$ is present in the thermal gases to understand the involvement of mantle in the evolution of the thermal springs in this area. Considering the reservoir temperatures indicated by the isotope signatures, emanation of high He content in the thermal gases and gravity anomaly pattern over the Bakreswar and Tantloi thermal sites, we find that these sites are potential areas for geothermal development as well as extraction of He from the thermal gases for commercial purposes. Pilot plants to extract and purify He from the thermal gases of Bakreswar and Tantloi are already in operation (Ghose and Chatterjee 1980; Ghose et al. 1989). Exploratory drilling for He extraction on a commercial scale combined with installation of 5 MWe binary power plant in Bakreswar and Tantloi sites are being undertaken based on hydrogeochemical and geophysical characteristics of the geothermal fields investigated by various works in the study area.

\section{Acknowledgements}

Authors are thankful to Prof. S Viswanathan for his valuable suggestions during the initial stages of the preparation of the manuscript. The authors extend their appreciation to the Deanship of Scientific Research at King Saud University through the research group project No. RGP VPP-122. They thank Prof. M Radhakrishna for rendering help in spectral gravity interpretation. Authors also thank the anonymous reviewer for the valuable suggestions, which improved the quality of the paper.

\section{References}

Acharyya S K 2003 A plate tectonic model for Proterozoic crustal evolution of central Indian Tectonic Zone; Gondwana Geol. Mag. Spec. 7 9-31.

APHA 1977 Standard methods for examination of water and waste water; American Public Health Association, Water and Waste Product Control Federation, 675p.

Ball J W and Nordstrom D K 1991 User's Manual for WATEQ4F with revised thermodynamic data base and test cases for calculating speciation of major, trace and redox elements in natural waters; U.S. Geological Survey, Open File Rep. 91-183.

Bandyopadhyay G and Nag S K 1989 A study on the hydrology and chemical characteristics of Bakreswar group of thermal springs, Birbhum district, West Bengal, India; J. Geol. 61(1) 20-29.
Bhattacharyya B K 1966 Continuous spectrum of the totalmagnetic-field anomaly due to a rectangular prismatic body; Geophysics 31(1) 97-121.

Bhattacharyya B K 1978 Computer modeling in gravity and magnetic interpretation; Geophysics 34(5) 912-929.

Chandrasekharam D 2000 Geothermal energy resources of India: Country update; Proceedings World Geothermal Congress 2000, Kyushu-Tohoku, Japan, May 28-June 10, 2000, pp. 133-145.

Chandrasekharam D and Chandrasekhar V 2010 Geothermal energy resources, India: Country update; World Geothermal Congress 2010, Bali, Indonesia, 25-29 April 2010.

Deb S and Mukherjee A L 1969 On the genesis of a few groups of thermal springs in the Chotanagpur Gneissic Complex, India; J. Geochem. Soc. India 4 1-9.

Desikachar S V 1974 Himalayan orogeny and plate tectonics - a geological interpretation; Geol. Surv. India Misc. Publ. 34 29-39, Part 1.

Dunn J A 1939 Post-Mesozoic movements in the northern part of the peninsular India; Geol. Surv. India Memoir 73 137-142.

Dunn J A 1941 Mineral resources of Bihar; Geol. Surv. India Memoir 78.

Fournier R O 1973 Silica in thermal waters: Laboratory and field investigations; Proc. Int. Symp. Hydrogeochemistry and Biogeochemistry, Tokyo 1 122-139.

Fournier R O 1983 A method of calculating quartz solubilities in aqueous sodium chloride solution; Geochim. Cosmochim. Acta 47 579-586.

Fournier R O and Truesdell A H 1973 An empirical Na-K-Ca geothermometer for natural water; Geochim. Cosmochim. Acta 37 1255-1275.

Gerard A and Debeglia N 1975 Automatic three-dimensional modeling for the interpretation of gravity or magnetic anomalies; Geophysics 40(6) 1014-1034.

Giggenbach W F 1988 Geothermal solute equilibria. Derivation of $\mathrm{Na}-\mathrm{K}-\mathrm{Mg}-\mathrm{Ca}$ geoindicators; Geochim. Cosmochim. Acta 52 2749-2765.

Giggenbach W F 1992 Isotopic shift in waters from geothermal and volcanic systems along convergent plate boundaries and their origin; Earth Planet Sci. Lett. 113 495-510.

Giggenbach W F and Goguel R L 1988 Methods of the collection and analysis of geothermal and volcanic water and gas samples; New Zealand, Department of Scientific and Industrial Research Report CD-2387, 53.

Giggenbach W F, Gonfiantini R, Jangi B L and Truesdell A H 1983 Isotopic and chemical composition of Parbati Valley geothermal discharges, NW-Himalaya, India; Geothermics 12 199-222.

Giggenbach W F and Soto R C 1992 Isotopic and chemical composition of water and steam discharges from volcanic-magmatic-hydrothermal systems of the Guanacaste Geothermal Province, Costa Rica; Appl. Geochem. 7 309-332.

Ghosh P K 1948 Mineral springs of India; Proceeding 35th Indian Science Congress, Part 2, pp. 221-250.

Ghose D and Chatterjee S D 1980 Genesis of the abundance of helium formation in natural gas emanating from thermal springs; Proceedings Indian National Science Academy Part A 46(1) 81-83.

Ghose D, Das S K and Chatterjee S D 1989 Occurrence of krypton and xenon in the Bakreswar thermal spring gases; Naturwissenschaften $\mathbf{7 6} 520-521$.

GSI (Geological Survey of India) 1991 Geothermal Atlas of India; Geol. Surv. India Spec. Publ. 19144.

GSI 2006 Bouguer gravity anomalies (Terrain corrected) superposed on geological map of India; A collaborative 
project of Geological Survey of India, National Geophysical Research Institute, Oil and Natural Gas Corporation Limited, Survey of India and Oil India Limited, Scale $1: 2000,000$

IAEA 2008 Atlas of isotope hydrology - Asia and the Pacific; IAES Water Resource Program Publ. 138.

Jacoby W and Smilde P L 2009 Gravity interpretation: Fundamentals and application of gravity inversion and geological interpretation; Springer-Verlag, Berlin, Heidelberg.

Kumar A and Ahmad T 2007 Geochemistry of mafic dykes in part of Chotanagpur gneissic complex: Petrogenetic and tectonic implications; Geochem. J. 41 173186.

Majumdar N, Majumdar R K, Mukherjee A L, Bhattacharya S K and Jani R A 2005 Seasonal variations in the isotopes of oxygen and hydrogen in geothermal waters from Bakreswar and Tantloi, eastern India: Implications for groundwater characterization; J. Asian Earth Sci. 25 269-278.

Majumdar N, Mukherjee A L and Majumdar R K 2009 Mixing hydrology and chemical equilibria in Bakreswar geothermal area, eastern India; J. Volcanol. Geotherm. Res. 183 201-212.

McDougall I and McElhinny M W 1970 The Rajmahal Traps of India - K-Ar ages and palaeomagnetism; Earth Planet. Sci. Lett. 9 371-378.

Minissale A, Vaselli O, Chandrasekharam D, Magro G, Tassi F and Casiglia A 2000 Origin and evolution of 'intracratonic' thermal fluids from central-western peninsular India; Earth Planet. Sci. Lett. 181 377-394.

Mukherjee A L 1964 Mineragraphic studies of desseminated bodies of magnetite in granite-pegmatite at Nawadiha in Hazaribagh district, Bihar; Proc. Indian Acad. Sci. Sect. B 60(5) 341-346.

Mukhopadhyay D K 1989 Interim report on Bakreshwar, Tantloi and adjoining hot springs in parts of Birbhum dist., WB and Dumka, Godda and Sahebganjdistt, Bihar; GSI ER, Unpubl. Report FS 88-89.

Mukhopadhyay D K and Sarolkar P B 2012 Geochemical appraisal of Bakreshwar-Tantloi hot springs, West Bengal and Jharkhand, India; Proceedings, ThirtySeventh Workshop on Geothermal Reservoir Engineering,
Stanford University, Stanford, California, January 30February 1, 2012, pp. 1-5.

Nagar R K, Vishwanathan G, Sagar S and Sankaranarayanan A 1996 Geological, geophysical and geochemical investigations in Bakreswar-Tantloi thermal field, Birbhum and Santhal Parganas districts, West Bengal and Bihar, India; In: Proceedings of the Seminar on Geothermal Energy in India (eds) Pitale U L and Padhi R N, Geol. Surv. India Spec. Publ. 45 349-360.

Nuti S 1991 Isotope techniques in geothermal studies; In: Applications of geochemistry in geothermal reservoir development (ed.) Franco D'amore, pp. 215-251.

ONGC (Oil and Natural Gas Commission) 1969 Tectonic map of India; Oil and Natural Gas Commission, Dehradun, India, scale 1:2000,000.

Parkhurst D L and Appelo C A J 1999 User's guide to PHREEQC (Version 2) - A computer program for speciation batch-reaction, one-dimensional transport, and inverse geochemical calculations.

Piper M 1944 A graphic procedure in the geochemical interpretation of water analyses; American Geophysical Union 25 914-923.

Reed M and Spycher N 1984 Calculation of $\mathrm{pH}$ and mineral equilibria in hydrothermal water with application to geothermometry and studies of boiling and dilution; Geochim. Cosmochim. Acta 48 1479-1492.

Sarkar A N 1982 Precambrian tectonic evolution of eastern India: A model of converging microplates; Tectonophys. $86363-397$.

Shanker R 1988 Heat-flow of India and discussion on its geological and economic significance; Indian Minerals $\mathbf{4 2}$ 89-110.

Shanker R 1991 Thermal and crustal structure of "SONATA". A zone of mid-continental rifting in Indian Shield; J. Geol. Soc. India 37 211-220.

Spector A and Grant F S 1970 Statistical models for interpreting aeromagnetic data; Geophysics 35(2) 293-302.

Telford W M, Geldart L P and Sheriff R E 1990 Applied Geophysics; 2nd edn, Cambridge University Press, New York.

Truesdell A H, Nathenson M and Rye R O 1977 The effects of subsurface boiling and dilution on the isotopic compositions of Yellowstone thermal waters; J. Geophys. Res. 82 3694-3704. 